\title{
THE GERMAN LAW OF ALIMONY BEFORE AND UNDER NATIONAL SOCIALISM
}

\author{
H. MANKIEWICz* \\ Translated by L. L. Fuller $\uparrow$
}

The law of alimony tends to be shaped by the conception which the legislator or judge has of the nature of marriage itself. It is therefore not surprising that National Socialism, as a consequence of its new conception of marriage as a "service to the folk-community" (Lange), has arrived at a regulation of the claim to alimony differing from the previous "liberal" regulations on the subject. This new conception found its legislative expression in a law passed July 6, 1938, and becoming effective August $x, 1938$, and which had for its general object the unification of the law of divorce and separation for the whole of Greater Germany, including Austria. ${ }^{1}$

It seems, however, inadvisable to pass at once to a consideration of this statute, which as yet has scarcely received judicial interpretation. The reforms which this statute introduces are to be understood only by placing them against the background of the previous law of the Civil Code, a body of law which has the advantage from our present standpoint of being more readily compared with other occidental systems.

What follows is divided into two main divisions, the first dealing with the law before the National Socialistic reforms, the second dealing with the present law. In both sections we shall consider first the relevant substantive provisions, and then the machinery of sanctions available for enforcing the claim to alimony.

- Docteur en Droit. General Secretary of the Institute of Comparative Law and of the Institute of Social Sciences and International Relations, both connected with the University of Lyons. Formerly VicePresident of the Labor Court at Frankfurt am Main, and a judge in the Prussian courts. Has pursued legal studies at the Universities of Frankfurt, Berlin, and Lyons. Author of La Conception Nationalsocialiste du Sens de la Vie et du Monde (1937).

tProfessor of Law, Duke University School of Law.

'Translator's Note. Mr. Mankiewicz very generously expressed his willingness that the translator of his article should be unconstrained by compunctions of literalness, and also gave his consent to such excisions from the article as might be necessitated by considerations of space. I have made very free use of the first branch of this indulgence, and a somewhat more sparing use of the second. The distance separating us has made communication during the process of translation impossible, though because of the extensive prerogatives which I have exercised such communication would have been particularly desirable in this case. I am indebted to Mr. Joseph Laufer, student in the Duke University School of Law, and to Dr. Ernst Morwitz for assistance on certain points of German law and legal terminology, though unfortunately it has not been possible for either of these gentlemen to check the accuracy of the translation as a whole.

${ }^{1}$ ReIChSGeSETZBLATt, x938, pt. I, p. 807 . 


\section{The Claim to Alimony under the German Civir Code}

\section{A. Fundamental Conceptions}

The German Civil Code, the relevant sections of which remained in force until August I, 1938, abstains from setting up a definite conception of marriage. This is understandable in view of the political composition of the Reichstag which enacted the code, the principles of the Catholic Center on this subject being scarcely reconcilable with those of the more "progressive" parties. The introductory paragraph

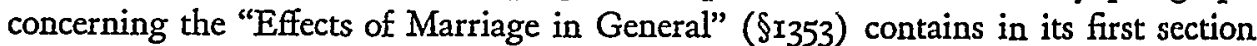
simply a rather colorless statement to the effect that "the spouses are mutually obligated to a conjugal life in common." According to the Kommentar der Reichsgerichtsräte ${ }^{2}$ this obligation embraces "all the duties, including those not specially mentioned in the code, which in accordance with the ethical nature of marriage flow from the personal relations of the spouses." "All the duties which are in this manner determined become legal duties."3

It corresponds entirely to the fundamental point of view of political liberalism, that the legislator should consider the institution of marriage only under its juristic aspect, and should consider himself as justified in imposing a regulation of the duties which flow from this "conjugal life in common" only to the extent to which these duties have been or can conveniently be converted into legal duties. It is therefore in my opinion wholly out of place to conclude, with the National Socialist jurists, that the Civil Code placed marriage legally on the plane of a "bilateral contract for sexual performance." A thorough study of the German case law before National Socialism shows, on the contrary, that the courts (perhaps more than the legislator) were fully aware of the ethical and institutional character of marriage. It was precisely on the institutional character of marriage that they relied in converting "merely" moral duties into legal duties capable of enforcement in order in this manner to hold the parties to an ethical conception of the marital bond. This attitude is especially clear in the treatment of divorce and in the attitude taken with regard to contracts for support made before divorce, which have for their purpose the "purchase" of the consent of one party to a dissolution of the marital bond, and which were therefore declared immoral and void by the courts. It would go beyond the purposes of this article to attempt to follow this body of case law in detail. Suffice it to say that the German courts of the pre-National Socialist era also viewed the "rights" asserted by the spouses in the light of the ethical nature of marriage, and gave them sanction only in so far as they were compatible with this nature.

Nevertheless the effects of marriage, derived from its institutional nature, were limited to the existing marriage. Direct effects projected into the future after the dissolution of the marriage were not considered to result from its institutional and ethical character. This was not altered by Article Irg of the Constitution of the German Republic of 19 rg which declares, "Marriage, as the foundation of family life

\footnotetext{
${ }^{2}$ Note 2 to 51353 .
}

s Reichsgericht in Das Recht, r908, No. 3439; LeIPziger ZeITschrRIFT, 1923, p. 45 I. 
and the preservation and increase of the nation, stands under the special protection of the Constitution." In his work on legal philosophy Radbruch shows how far this conception of marriage differs from a purely ethical view of the marital bond, such as is found in the canonical law, and departs from that view precisely in that it presents marriage under a "secular and political point of view." From a "secular and political point of view" it is only the actually existing marriage, or the marriage which is to be kept alive, which can claim the protection of the legal order. The dissolved marriage is without pressing legislative importance.

From these considerations flows the attitude of the legislation of political liberalism toward the regulation of alimony after divorce has been granted. This regulation finds its foundation not in the nature of marriage, but in the grounds for its dissolution. The dissolved marriage necessarily loses its ethical and institutional character. The problem becomes merely a matter of the financial liquidation of a previously existing legal relation. The peculiar nature of this legal relation finds only a continued feeble expression in the special character of the sanctions given the claims arising out of this liquidation, and the special nature of these sanctions is attributable not so much to their origin as to their peculiar object, which is the providing of support for the claimant. It is not surprising that the contractual nature of marriage should overshadow its ethical and institutional character precisely at the time of divorce, when the parties to the marriage wish to free themselves from the chains of this "conjugal life in common." It is naturally the contractual nature of marriage, so prominently to the fore at the time of its "liquidation," which sets the tone for the regulation of such matters as alimony. It would, however, be a mistake to conclude from this that the "liberal citizen" views marriage purely as a bilateral contract. Those marriages which become merely burdensome contracts present a minority, even though in recent years they have become a considerable proportion of the existing marriages in Germany, and surprisingly have increased appreciably during the first years of the National Socialist régime, which wishes to restore to marriage its institutional character as modified by the National Socialist conception of the "Volk." On the other hand, it certainly cannot be denied that the fact that marriage could be dissolved almost as if it were an ordinary private contract influenced many to enter that relation who would not have assumed the marital bond had it been conceived as founding a broader obligation. As a result, many marriages were

4 The following figures indicate the number of divorces per 10,000 marriages granted in Germany for the period 1929-1937:

\begin{tabular}{|c|c|}
\hline Year & $\begin{array}{l}\text { Number of divorces } \\
\text { per 10,000 marriages }\end{array}$ \\
\hline $1929 \ldots$ & . . . . 29.0 \\
\hline $1930 \ldots$ & .....29.5 \\
\hline $1931 \ldots$ & $\ldots \ldots .28 .5$ \\
\hline $1932 \ldots$ & ......29.7 \\
\hline $1933 \ldots$ & . . . . .29.7 \\
\hline I934 $\ldots$ & …...37.0 \\
\hline I935.... & . . . 3.3.0 \\
\hline $1936 \ldots$ & $\ldots \ldots \cdot 3^{2.6}$ \\
\hline $1937 \ldots$ & . . . . 29.8 \\
\hline
\end{tabular}


entered under the aegis of contract, insteadi of under that of a moral community of life-interests.

\section{B. Basis and Scope of the Claim to Alimony}

When marriage is viewed from a secular and political point of view it necessarily loses every institutional and ethical quality on dissolution, and can have meaning only as a previously existing legal relation. From such a conception it follows that the reciprocal claims of the spouses on dissolution of the marriage can properly be determined only by principles of contract law. The notion of contract violation is therefore determinative not only for the establishment of these claims but also for their scope.

The acceptance of culpable contract breach as the basic theory of liability leads logically to the following principles concerning alimony, which are in fact declared in the sections of the Civil Code indicated in parentheses:

(I) Ai claim to alimony exists only against a party to blame for the divorce and in favor of an innocent party. If both spouses are at fault, neither can claim alimony. $(\$ 1578)$

(2) If the alimony claimant is the wife, it is presumed that she exercises no gainful occupation, and her right, in accordance with general principles of contract law, is to secure "what she would have had, had the damaging event not occurred" (\$249), which as applied to this case means that she is entitled to receive the maintenance befitting her station. ( $\$ 1578$ ) "Maintenance befitting her station" is construed to refer to the status of the husband at the time of divorce, and not to the status which he may later occupy. ${ }^{5}$ An increased need, for example, as the result of illness, gives no right to an increase in alimony payments. ${ }^{6}$

(3) The "damage" which the wife suffers is, however, reduced if "according to the circumstances in which the spouses lived, earning by the wife's labor is customary." In this case the husband declared to be at fault in the divorce proceeding is bound to supply a maintenance befitting the wife's station only in so far as her own earnings are insufficient for that purpose. ${ }^{7}$

(4) Similarly, if the wife enjoys an income on property of her own, the husband is bound to provide maintenance only in so far as the wife's income is insufficient for that purpose. ( $\$ 1578$ ) Again, this result is not inconsistent with general principles of contract law, but represents, on the contrary, an application of them. Under the German law of marital property rights the husband has the management and use of the wife's property during the marriage, except under the régime of separate property. Even under that régime the wife is bound to contribute to the matrimonial expenses from her separate income. ( $\$ 1427$ ) Accordingly, the reduction of her claim to alimony by the amount of her separate income is simply an application of the general theory that she should be placed in the position she would have occupied had her

\footnotetext{
${ }^{5}$ Reichsgericht, Oct. 26, 1936, IV, I69/36; JURISTISChe Wochenschrift, I937, p. 465.

- Landgericht Berlin, Nov. 3, 1934; Juristische Wochenschrift, 1935, p. 70.

"Concerning the concept of "customary," see ReIchsgericht, Oct. 26, 1936, IV, I69/36.
} 
husband not wrongfully caused a termination of the marital relation. It is on the same theory that the divorced wife is not bound to touch the principal of her capital, even though she may be quite rich and her husband dependent on his earnings. During the marriage she was not bound to expend her principal, and to compel her to do so now would represent a "damage" to her.

(5) During marriage the wife is bound to provide for the maintenance of the family in so far as the husband is unable to do so. Accordingly, as a logical consequence of the principles already mentioned, in case of divorce the wife adjudged exclusively guilty is bound to provide her husband with a maintenance befitting his station in so far as he is unable to support himself. ( $\$_{57} 78$ )

The claim to alimony arises when the divorce decree goes into effect. Pending the litigation the court having jurisdiction over the divorce proceeding can make a pro visional disposition of the problem of maintenance to last until the divorce decree becomes effective. (Code of Civil Procedure, \$627) The court, which in this matter is granted a wide discretion, is expected to follow the general principles laid down in $\$ 136 \mathrm{r}$ of the Civil Code. The court must, accordingly, deny or restrict the husband's obligation of maintenance where to do so "would be equitable in view of the needs as well as the means and earning capacities of the spouses." The court has the power furthermore to reduce the wife's claim to the barest necessities where it is convinced that she has been guilty of a moral offense. 8

It is only a necessary consequence of the conception underlying the regulation of the claim to alimony that the claim ceases with the death or remarriage of the claimant. ( $\$$ I $_{58} 8 \mathrm{I}, \mathrm{I}_{582}$ ) (The heirs of the claimant can recover only sums due and unpaid at the time of the claimant's death. ( $\$ I_{5} 80$, par. 3 , in combination with $\left.\$ 1615\right)$ ) The death of the obligor, on the other hand, does not destroy the claim, although in that case, according to Section 1582 , par. 2 , the claimant must consent to a reduction of the alimony payments to one-half of the income which the obligor derived from his property at the time of his death.

I am fully aware that the conception of alimony as a kind of transfigured claim to damages stands in a certain contradiction with the conception which prevailed in Germany even before National Socialism. The Kommentar der Reichsgerichtsräte declares, for example," "Guided by the conception that to treat marriage as a source of financial advantages would be to contradict the nature of that institution, the Civil Code has joined to divorce a claim to maintenance limited to necessities. In the definition of this claim the prevailing notion has been that of an equitable after-effect of the marriage." This conception seems out of place, on the one hand, because it is precisely not a matter of a "claim to maintenance limited to necessities," but of a claim to support befitting the claimant's station in life, and, in the second place, because it is difficult to see why, from this point of view, the claimant should be limited to a right to continue the standard of life enjoyed during marriage, and

\footnotetext{
${ }^{8}$ See Stein \& Jonas, Die Zivilprozessordnung fuer das Deutsche Reich (1929) III, 2, on $\$ 627$ of the Code of Civil Procedure.

${ }^{\circ}$ Note $\mathrm{I}$ to $\$ 1578$.
} 
should be excluded from participating in a subsequent improvement in the status of the obligor. Furthermore, the extinction of the claim on remarriage is justified, as we shall show later, on quite other grounds than "an equitable after-effect of the marriage." The conception of alimony as basically similar to a claim to damages is further indicated by the fact that the provisions of Section I6II are not made applicable to alimony so as to reduce or destroy the claim in case the obligee is guilty of some fault toward the obligor after divorce. ${ }^{10}$

It is of course perfectly true that the conception of marriage as a mere contract and the construction of alimony as a claim to damages are not notions which are overtly declared. Their open avowal would of course be shocking to a community of rightthinking citizens. Nevertheless the solemn declarations of the Supreme Court cannot, in my opinion, change the fact that, under the system of the Civil Code, marriage is, after its dissolution, viewed in retrospect as a mere contract, or that the claim to alimony granted by the Code is in effect construed as a claim to damages. To be sure, it is a claim to damages of a special character inasmuch as it is directed toward obtaining maintenance. Accordingly, it is subjected not to the statutory provisions governing money claims generally but to those specially established for claims to support.

This is the reason for the relativity of the scope of the claim, the satisfaction of which, in contrast to ordinary claims to damages, will not be allowed to lead to the economic ruin of the obligor. Section 1579 lays down accordingly a special rule for the case where the obligor "in view of his other obligations is unable to provide maintenance for the obligee without imperilling his own maintenance according to his station." In this case the obligor is permitted to retain for his own maintenance two-thirds of the income available for his maintenance, and if this is not sufficient, then to retain so much as may be required therefor. If he has to support an unmarried minor or a second wife, his obligation is restricted to "that which with regard to the needs as well as the means and earnings of the parties, corresponds to equity." Furthermore, in this case, and only in this case, is the husband freed from the obligation to support his former wife, if the wife can provide for her own maintenance out of the principal of her property. (\$1579, par. 2) Finally, the claim is limited by the provision of Section I6rI (in combination with Section 1582, par. 2) that "one who comes in want through his own moral delinquency can demand only the barest necessities for his maintenance," though, as has already been pointed out, a moral offense toward the obligor which does not affect the obligee's ability to support himself is without effect on the claim to alimony.

The scope of the claim is, therefore, not set once and for all. It varies with the advance or decline of the obligor's economic situation. Machinery for effectuating this variation is provided by Section 323 of the Code of Civil Procedure, which reads, "In case there occurs an important change in the circumstances which were determinative in entering a decree for performance or in setting the time for performance,

${ }^{10}$ ReICHSGERICht, Oct. 29, 1934, IV, 139/34; JURISTISChE WOChENSCHRIFT, r934, p. 327 . 
either party is empowered to bring an action for the purpose of securing an appropriate alteration in the decree." The same principles are applied by the court where the amount of alimony is set by contract, indeed, even where the contract contains an express waiver of the right to apply for modifications. ${ }^{11}$ This is on the basis of a tacitly assumed clausula rebus sic stantibus. It should, however, be observed that the court imposes extraordinarily strict requirements before it will modify a contract for alimony. There must exist such a disparity between the former and the present situation of the party, or parties, as to destroy the underlying basis for the contract. ${ }^{12}$

Concerning contracts settling the question of maintenance and entered into by the parties before the decree of divorce, it may be said generally that the court has always viewed such contracts with great distrust. Proceeding from the consideration that the legislator intended to preserve existing marriages as long as possible, the court declared to be incompatible with the nature of marriage, and therefore immoral, all contracts which were intended to make possible or facilitate a divorce. Plainly objectionable, from this standpoint, were contracts where a promise of support, or a waiver of the claim to support, was made for the purpose of inducing the other party's consent to a divorce. Contracts for support were only valid where the party entitled to divorce was already determined to bring a suit for divorce in any event. The borderline between the permissible and unpermissible in this field was unusually vague. We shall forego a detailed discussion of the cases, however, since the question is now expressly governed by statute, and a source of constant uncertainty has, at least in appearance, been removed.

\section{Enforcement of the Claim to Alimony}

The claim to alimony is basically a claim to periodic payments. ( $\$ 1580$, par. I) An income can, however, of course, be secured through the payment of a lump sum, and Section 1580 , par. 2 , provides that where an important reason exists, the party entitled to alimony may demand an adjustment by a capital sum.

Provision is furthermore made for rendering secure the obligation to make future periodic payments. The procedure for obtaining security for future performances generally by a sequestration of the debtor's property is made subject by the Code of Civil Procedure to certain conditions which are not always easily established. On the other hand, a decree in personam directing the obligor to render security for the performance of obligations as yet unaccrued is an unusual procedure. Because of the peculiar character of the claim to support, Section 324 of the Code of Civil Procedure creates a special claim to security for future performance in this case. According to this section the obligee can demand security, though none was provided in the original decree, or can demand an increase in the security originally provided, "where the economic condition of the obligor has become worse to a significant degree." In

\footnotetext{
${ }^{21}$ ReIchsgericht, May 27, I935, IV, 19/35; JURISTISChe Wochenschrift, I935, p. 2619.

12 ReICHSGericht, July 5, I934, IV, 25/34; JuRISTISCHE WOCHENSCHRIFT, I934, p. 2609; REICHPGERCHT, Nov. 26, I935, VII, I34/35; JURISTISCHE WOCHENSCHRIFT, I936, p. 927.
} 
this case it is accordingly not necessary to prove that the performance of future obligations has actually been endangered.

The special nature of the claim to alimony finds expression also in the preferred position enjoyed by the creditor in the matter of enforcing the claim through garnishment, an advantage which this claim shares with all other claims to maintenance. Section $850(4)$ of the Code of Civil Procedure (concerning the amendment to which by the Law of October 24, 1934, we shall have occasion to speak later) provides that the limitations on the right to garnishee debts due the defendant, in the form of exemptions favoring the salaries and pensions of certain classes of persons, have no application where the garnishment is demanded to enforce the payment of a statutory obligation to provide support arising since the action to secure support was commenced or during the three months preceding the bringing of the action. ${ }^{13}$ This special right to reach by garnishment debts otherwise immune from the claims of creditors is granted only because the claim enforced is one for the living expenses of the plaintiff. The preferred status of the claim is, therefore, destroyed by its assignment to a third person. ${ }^{14}$

A word may be added concerning the attitude of the courts toward debtors who have attempted to make themselves execution-proof by fraudulent transactions. Such a case is presented, for example, where the husband adjudged at fault in the divorce proceedings conveys his business to a second wife and works for her "gratuitously" or where he assigns to her his future earnings. The courts have always proceeded very severely against such debtors. They have, furthermore, through an application of Section 826 of the Civil Code, declared the favored third person liable for damages where he knew that the purpose of the transaction was to remove the property or earnings of the debtor from the reach of his creditor.

The claim to support is given a criminal law sanction by Section $36 \mathrm{x}(\mathrm{ro})$. The punishment here provided (imprisonment or a maximum fine of 150 marks) is incurred by one who "although he is able to provide support for the person toward whom he is obligated, evades his obligations, in spite of the demand of competent authorities, in such a manner as to make it necessary for the authorities to secure help from another source," as, for example, when the obligee becomes a charge on public charity. Obviously there are practical difficulties in the application of this provision to debtors in modest circumstances who are dependent on their own earnings. A sentence of imprisonment runs the risk of depriving such a person of his job, while, on the other hand, the collection of a fine, along with court costs, can easily deprive him of the only resource out of which he could have met the claim.

\footnotetext{
${ }^{13}$ It should furthermore be remarked that claims held by the obligor which according to the Insurance Code would not ordinarily be garnishable are by $\$ 819$ of that statute made subject to garnishment in favor of an alimony claimant. KAMmergericht, May 27, 1930, $8 \mathrm{~W} 3754 / 30$; JuRISTISche WoCHENSCHRIPT, I932, p. 1403 .

The claim to support is also given a preferred status inasmuch as it may be enforced through a garnishment of wages to an extent not otherwise permitted by the statutory provisions relating to that subject. The present law on this subject, established by the Law of October 24, 1934, is discussed later.

x4 See Stein \& Jonas, op. cit. supra note 8 , note IV, 2-a, to $\$ 850$ of the Code of Civil Procedure.
} 
The practice is therefore to suspend the sentence if the debtor promises to provide the support promptly. If he defaults on an instalment, the criminal proceeding will be reopened. This expedient suffices in the majority of cases to induce payment. Though one may entertain legitimate doubts as to the legal propriety of such a manipulation of the criminal proceeding, there is no doubt that from a practical standpoint it is the only effective procedure.

\section{The Claim to Alimony under the National Socialist Law of July 6, i938}

\section{A. Fundamental Conceptions}

In the system of National Socialism marriage is deemed to have an essentially different meaning and function than under a "liberal" régime. This new conception of marriage is, of course, not without influence on the claim to alimony.

In the world-view of National Socialism, which rests on the racial principle, and which has as its highest aim the development of a racially pure community, marriage demands and secures the protection of the state because, and in so far as, it is the wellspring of new racial life. Only those marriages are basically deserving of protection in which racially worthy spouses have united for the purpose of bringing into existence the largest possible number of biologically desirable children. According to the "official explanation"15 of the Law of July 6, 1938, the National Socialist conception of marriage differs from that of Liberalism in that it does not, like the latter, "see in marriage a contract-like union entered for the purpose of realizing individual interests. ... On the other hand, National Socialism does not, like the confessional viewpoint, consider the sanctity of the institution of marriage to lie in other-worldly conceptions or religious associations, but in the meaning of marriage for the maintenance and health of the German Folk." For "marriage serves primarily the preservation and increase of the Folk."

Accordingly the state which bases itself on the National Socialistic world-view, and which seeks the realization of this world-view in all fields of life, will not concern itself with those marriages which are "worthless" for the community because racially desirable children cannot result from them. In this respect, a marriage which was worthless from the standpoint of the community would be basically indifferent to the National Socialist state. If the state cannot, however, wholly ignore such marriages, this arises from the fact that any marriage presents a kind of molecule of order inside the larger order of the Folk, and a shattered marriage would disturb the order of the community if it were not liquidated in an orderly manner. Liquidation in this sense includes a proper regulation of the question of support, which, on the one hand, facilitates the dissolution of a marriage become burdensome, and, on

${ }^{15}$ Translator's Note. The expression "official explanation" is intended as a translation of the word "Begründung." The German statutory Begründung is an institution for which there exists no exact counterpart in our legislative practice. It is, as a matter of fact, usually more than an explanation of the statute; it normally describes in some detail the need which gave rise to the statute, often reviews briefly the previous state of the law, and generally explains and justifies the action of the legislature. It is less formal and more detailed than the statutory preamble which occasionally performs a somewhat similar function with us. Its closest analogue in this country would be the notes and commentaries which sometimes accompany the recommendations of law revision commissions. 
the other, by creating a kind of order between the divorced spouses consistent with the general order avoids disturbing the latter. An additional consideration is that "particularly in the National Socialist state care must be taken that the smallest possible number of members of the Folk shall be dependent for support on public charity." ${ }^{16}$

The National Socialist regulation of alimony is, accordingly, primarily concerned with questions of expediency. It is therefore characteristic that the official explanation of the Law of July 6, r938, in spite of its considerable length, refrains from any detailed discussion of the moral and legal reasons for the right of alimony granted by the statute, and confines itself to a reference to the "new conceptions."

If one proceeds from the conception of marriage as an institution ("order" in the National Socialist sense) creating its own law, then the regulation of claims to alimony results from the nature of marriage itself, and the question of fault can have only a subsidiary and modifying effect on the granting of alimony. Entrance into the marital status involves an engagement binding the spouse for life. This engagement continues even when the marriage, for whatever reason, is dissolved. The question who was to blame for the dissolution can affect this engagement only in so far as the existence and scope of a moral engagement is always influenced by the conduct of the person toward whom the engagement is contracted, and in so far as a moral fault can be unequivocally attributed to one party. And when, in an inner relationship like marriage, is this really possible?

The duty to pay alimony appears properly therefore not so much as an aftereffect of the marriage as of the undertaking involved in the act which creates the marriage. This engagement, once undertaken, embraces the whole life of the party for his whole life, and cannot be affected by the dissolution of the marriage. It follows from this ethical and institutional view that basically each spouse is bound to support the other whenever the need for support arises. It follows further that the extent of the obligation is independent of the "station" of the spouses during marriage, and must be determined by the actual relevant circumstances of the parties at the time the support is supplied.

It is not our intention to provide a supporting argument for the National Socialist reforms of the law of alimony, an argument which could not, in any event, claim to be authoritative. Nevertheless is it undeniable that these reforms, in spite of the racial conception of marriage which underlies them, approach closely the rules which result from the conception of marriage as an institution founded on a purely moral basis.

\section{B. Basis and Scope of the Clain to Alimony}

Since National Socialism views marriage primarily as a purposive institution, it permits divorce even where no fault is present whenever a marriage cannot in fact

\footnotetext{
${ }^{10}$ Moessmer, Neugestaltung des Deutschen Ehescheidungsrechts, vorgelegt von dem Vorsitzenden des Familienrechtsausschusses der Akademie für Deutsches Recht, Semripten der AKademe fuER Deutsches RECHT, BERLIN.
} 
fulfill its purpose and, a fortiori, where it creates a discordant element in the general order of the community. ${ }^{17}$ It should be remarked that National Socialism has here, though with a different asserted justification, fulfilled a demand which had been made and actively campaigned for in socialist circles under the Weimar Republic.

As a result of this recognition of divorce for "objective" reasons, not dependent upon a showing of fault, the new law, in contrast to the Civil Code, distinguishes fundamentally between two different cases of alimony: $(x)$ where divorce results from the fault of one of the spouses, and (2) where the divorce does not rest on fault. The circumstance that these two cases are given separate treatment, and that furthermore the "divorce for fault" is regarded as the principal or ordinary case, shows that the new regulation is not derived from the institutional character of marriage, and that, in spite of all assurances to the contrary, it bears a rather close relation to the system of the Civil Code.

In case one spouse is exclusively at fault in the divorce, the rules of the Civil Code remain basically unaltered. (\$66) New, however, is a provision that a claim to alimony arises in the case of a divorce where both spouses are at fault, provided the predominant fault is declared to rest with one party. The party predominantly at fault is placed on the same footing as the party exclusively to blame for the divorce. (\$66) According to the official explanation of the statute, this reform rests on the following considerations, the justice of which will be testified to by anyone who has been occupied with divorce litigation, either as judge or attorney. "The decision of the spouses to take the decisive step and ask for a divorce will often depend upon the anticipated disposition of the question of alimony. The rules concerning alimony have an even greater influence on the question in what manner and with what means

${ }^{17}$ The relevant sections of the new law are as follows: "II. Divorce for other Reasons [than fault]. \$50. Conduct resulting from mental derangement. When, as the result of conduct by one spouse, which cannot be regarded as culpable because it results from mental derangement, the marriage is so fundamentally disturbed that a restoration of a common life corresponding to the nature of marriage cannot be expected, the other spouse may demand a divorce. $\$ 5 x$. Insanity. A spouse may demand a divorce where the other is insane, if the insanity has reached such a degree that intellectual and spiritual communion between the spouses has been destroyed and if a restoration of such communion cannot be expected. $\$ 52$. Contagious or loathsome disease. A spouse may demand a divorce where the other suffers from a serious and contagious or loathsome disease, and the cure of the disease or the removal of the danger of contagion cannot be expected within a foreseeable period of time. \$53. Sterility. (I) A spouse may demand a divorce where the other has become prematurely sterile since the marriage. (2) Divorce is excluded if the spouses have in common legitimate and biologically sound issue, or if they have a biologically sound child which they have adopted in common. (3) One who is himself sterile, has no right to a divorce. The same applies to a spouse who would not be permitted to enter a new marriage for reasons of health, or whom the Department of Health would have to advise not to remarry. \$54. Avoidance of hardship. In the cases provided for in $\$ \$ 50-53$ divorce may not be granted where the demand for it is not ethically justified. This is assumed to be the case in general where the dissolution of the marriage would visit an unusual hardship on the other spouse. Whether this is the case depends upon the circumstances, particularly on the duration of the marriage, the age of the spouses, and the cause of the insanity, disease, or sterility. \$55. Dissolution of common domestic life. (I) Either spouse may demand a divorce if cohabitation has not existed for three years, and if, as the result of a profound and incurable disturbance of the marital relation, restoration of a life in common corresponding to the nature of marriage cannot be expected. (2) If the spouse who demands the divorce was wholly or predominantly to blame for the disturbance of the marriage, the divorce may be opposed by the other. This opposition is not to be heeded where the preservation of the marriage is not ethically justified in the light of a proper estimation of the nature of marriage and of the whole conduct of the two parties." 
the litigational battle of the divorce suit will be carried on. The often deplored bitterness which characterizes so many divorce suits arises not so much from a sense of injury for wrongs suffered during marriage as from a concern by the one party lest the claim to alimony be lost, or by the other party to avoid the imposition of a burdensome liability." The hope of the legislator was to avoid this disagreeable aggravation of the unpleasantness more or less inevitable in a divorce proceeding by making predominant fault the equivalent of exclusive fault.

A further innovation consists in the fact that the maintenance provided is no longer defined as that "befitting the station" of the obligee but as that "appropriate to the circumstances of the spouses." (\$66) Decisive are the circumstances in which the parties find themselves when the support is furnished, not those which existed during the marriage. It results that the party entitled to support participates as a matter of course in the subsequent economic fate, good or bad, of the obligor. The consequence of this innovation is that the claim to alimony loses its character of a claim to damages and reveals itself as a true after-effect of the broad engagement underlying marriage itself. This basic reform in theory is accomplished even though the official explanation of the statute contents itself with a reference to "present conceptions," and a commentator justifies the innovation by saying that "there is no room in the new law for the obsolete conception of a support 'befitting the station in life' of the party laid down in $\$ 5778$ of the Civil Code."18

The distinction between the treatment of the claim to alimony by the innocent wife against the guilty husband, on the one hand, and that of the innocent husband against the guilty wife, on the other, is retained, since the husband is still only granted a claim to alimony where he is unable to support himself.

On the other hand, the wife's claim to alimony is altered somewhat by the fact that her own earning capacity is taken into account not simply where "according to the circumstances in which the spouses lived, earning by the wife's own labor is customary" (Civil Code, $\$ 1578$ ), but instead whenever "according to the circumstances it can be expected that the wife should carry on a gainful occupation." (\$66) Accordingly, the decisive point is not what was usual according to the position of the spouses during marriage, but what can reasonably be expected in the light of the circumstances existing at the time the support is provided. This disposition of the matter would seem also properly to flow from the fundamental engagement underlying the marriage. It is, however, justified by the official explanation of the statute in the following language: "In view of the position in economic life, as well as generally in the social structure of the Folk, which is today accorded the gainfully occupied woman, and in view of the modern conception of the worth of labor as a duty toward the folk-community, the answer to the question whether the divorced wife's claim to alimony can be eliminated or reduced by her own earning capacity can no longer be made to depend upon what ... was usual under the circumstances in which the

\footnotetext{
${ }^{18}$ AUert, Das neue grossdeutsche Eherecht (r938) note 2 to $\$ 66$.
} 
parties lived during marriage but upon what ... can reasonably be expected in the light of all the circumstances."

We have previously outlined the somewhat elaborate dispositions of the Civil Code for the case where the obligor, because of his circumstances or other obligations, is unable to pay the alimony to which the obligee would normally be entitled. Section 67 of the new law provides that in this case the obligor "need only provide so much as corresponds to equity in view of the needs of the spouses and their property and earning capacities. Where the obligor has to support unmarried minor children or, as the result of remarriage, a new spouse, the needs and economic conditions of these persons are to be taken into account." There is revealed in this provision the general effort of National Socialist legislation to preserve elasticity in statutory law in order to give to the judge in generous measure the opportunity to find the decision which seems just in view of all of the circumstances of the particular case.

The same considerations of equity find expression also in the most fundamental reform of the law of alimony contained in the Law of July 6 , I938. Section 68 provides that even where divorce is granted on the basis of mutual and equal fault, the spouse who lacks means of support may demand from the other spouse a "contribution to his or her support ... when and in so far as this corresponds to equity in view of the needs, property, and earning capacity of the other spouse and of the relatives of the necessitous spouse who, according to $\$ 7 x$, are obligated to support him or her."

This obligation to assist the spouse who comes in need, which is independent of the question of fault, can in fact only be understood as an after-effect of the moral obligation assumed in entering matrimony. For that reason it is all the more striking that the official explanation of the statute contains no real statement of the bases for this important and, in my opinion, most desirable reform. The explanation merely states that in changing the previous rigid system it was not thought wise to follow the advice of those who have urged "that even the exclusively guilty spouse should under certain circumstances be given, temporarily at least, a claim to support against the innocent spouse. Such a step could scarcely be reconciled with the natural sentiment of the people or with their conception of the meaning of the rights and duties involved in marriage, and would produce the danger of a relaxing of marital morality generally. The conditions for the granting of alimony shall for the future therefore only be lightened to the extent" already mentioned. In this connection one recalls also the claim asserted by the commission of the Academy for German Law on the basis purely of considerations of expediency that "particularly in the National Socialist state care must be taken that the smallest possible number of members of the Folk shall be dependent for support on public charity."

A peculiarity of this exceptional right granted by Section 68 to the spouse who shared in the fault for the divorce lies in the fact that it is a subsidiary claim. Although, as in the previous law, the obligation of the spouse to provide support generally precedes the similar obligation of the relatives of the spouse entitled to alimony, the "extraordinary" claim granted the necessitous spouse by Section 68 arises only 
when and in so far as its allowance appears to be just in view of the property and earning capacity of the relatives of the spouse in need. (A further peculiarity of this claim, concerning the effect of the death of the obligor, will be mentioned in a moment.)

Under the new law a divorce may be granted, as we have previously mentioned, for "objective" reasons even though no fault of either spouse is established. If a divorce is granted solely on the basis of such "objective" grounds, Section 69 imposes on the party who asked for the divorce a duty to support the other. This duty is described in much the same terms as those used in Section 68 in imposing a duty of support in the situation of equal fault, except that it is not expressly provided that the spouse claiming assistance be without other means of support.

The provisions relating to the extinction of claims to alimony have also been altered, partly in order to give effect to the conception of equity and judicial discretion which pervades the whole statute, and partly in order to adjust the previous law on this subject to the new substantive provisions concerning alimony.

The statute preserves, in Section 73(r), the previous rule according to which "an alimony claimant who comes in need through his own moral delinquency can demand only bare necessities for his support." The new statute further specifically provides that "an increased need which has resulted from the gross fault of the obligee provides no basis for a claim to increased support."10

A new provision concerning the forfeiture of the claim to alimony has been added to fill a gap in the law of the Civil Code discussed previously. According to Section 74 the claim to alimony is forfeited if after the divorce "the obligee is guilty of a serious fault toward the obligor or against the will of the latter leads a dishonorable and immoral life."

The provisions concerning the effect of the remarriage or death of the obligor are in general retained. It is provided, however, in Section 78(3) that the extraordinary claim to assistance granted by Section 68 to the necessitous spouse in cases of equal fault is completely extinguished by the death of the obligor. This result is consistent with the conception underlying this claim, which departs so completely from the notion of indemnity for damage suffered. Section $78(2)$ also brings about a certain change in the effect of the death of the obligor on claims to alimony generally. In place of the purely mechanical restrictions on the obligation of the heirs contained in Section 1582 of the Civil Code, the new law provides that the obligor "must consent to a reduction of the payments in an amount which corresponds to equity in view of the condition of the heirs and the productiveness of the estate."

Because of its basic attitude toward marriage and its effort to regulate the problem of alimony not so much according to juristic conceptions as according to considerations of equity, National Socialism was in a position to accord a different treatment to the contract for alimony entered into before divorce than that which it had been given by the courts. Section 80 accordingly provides: "The spouses may enter

\footnotetext{
${ }^{10}$ Concerning the previous law on this point, see JURISTISCHE WocheNSCHRIFT, I935, p. 70'.
} 
agreements affecting the duty of support after divorce. In case such an agreement is entered into before the divorce decree goes into effect, it is not void simply because it facilitated or made possible the divorce. [The case law on this point had been to the contrary, as we have previously mentioned.] Such an agreement is, however, void when the parties in connection with the agreement have set up an inexistent or no longer existing ground for divorce, or whenever it otherwise appears from the contents of the agreement or from other circumstances of the case that the agreement is contrary to good morals." Just how far this formulation of the rule has brought about greater legal certainty appears at least to be doubtful. One can hardly avoid applying here the expression that the devil has been driven out by Beelzebub.

By way of summary it may be said that the new law, in so far as it departs from the dispositions of the Civil Code, is distinguished from the code principally by an extensive introduction of considerations of equity. It enables the judge to take generous account of the special circumstances of the individual case, and in this manner permits a disposition of the problem of alimony satisfying to the sense of right and morality. One can say of the new law of alimony what has been said of the even more elastic new divorce provisions, "everything depends on the judge."20 This remark is all the more appropriate in view of the fact that the new law, as so frequently the case with National Socialist statutes, is ambiguous as to its fundamental justification and may, therefore, be interpreted from different points of view even where no discretion is expressly conferred on the judge.

Not unjustified seems also the hope of the legislator that this new law, which gives the judge at once a great responsibility and a great freedom, will permit divorce and alimony litigation to be conducted with less bitterness than heretofore. The individual is no longer called on to "prove his rights," but rather to cooperate to bring about an equitable disposition of the case. The elastic formulation of the rules concerning alimony make it furthermore evident to the parties that even after divorce they are not strangers to one another, but that each participates in the subsequent life and fate of the other.

\section{Enforcement of the Claim to Alimony}

The possibility of disposing of the claim to alimony through the payment of a capital sum is preserved in the new law. A claim to this capital adjustment exists however, not, as in the previous law, simply where an "important reason exists" but only where such a reason exists and the capital adjustment will "not inequitably burden the obligor." ( $\$ 70(2))$

Where alimony is paid in periodic instalments, Section $70(\mathrm{I})$ of the statute provides, "The obligor must furnish security when the danger exists that he is seeking to evade his obligation. The form of the security is to be determined according to the circumstances." Section 324 of the Code of Civil Procedure, discussed earlier in this paper, remains in effect.

\footnotetext{
${ }^{10}$ SchWARZES KORPs, July $28,1938$.
} 
As has already been mentioned, the statutory provisions relating to the advantages enjoyed by the claim to alimony in the matter of enforcement through garnishment have also been altered by the Law of October 24, r934, amending Section 850 of the Code of Civil Procedure. The new Section 850-a, like the old, provides that the "salaries of officers of the government and ministers, as well as of physicians and teachers in public institutions, and the pensions of these persons during permanent or temporary retirement" shall be exempt from execution to the amount of 150 marks a month. In case the sum received exceeds 150 marks a month, two-thirds of the excess shall also be exempt from execution. Subsection 3 provides, again following the previous law, that statutory claims to support may be enforced without reference to the limitations just stated. It is, however, provided that in this case so much shall be left to the debtor as is required for his own necessary support or for fulfilling his current statutory obligations to claimants to support having priority over the plaintiff. The amount thus left to the debtor shall not exceed, however, the total amount made normally exempt from execution by general creditors. ${ }^{21}$

A laudable change in previous law is effected by the last sentence of Subsection 3 which states that in those cases where the claim to support accrued more than one year before garnishment was asked the claim shall be granted a preferred status only in so far as there is reason to believe that the debtor has purposely evaded his duty toward the claimant. Whether this situation exists is determined not by a formal trial, but through an informal procedure on the motion for garnishment.

We have already spoken briefly of the German case law concerning fraudulent conveyances. The Law of October 24 , I936, contains two provisions materially facilitating the procedure against the defrauding debtor and his accomplice. These provisions apply in favor of any creditor, no matter what the origin of his claim may be, but it is not inappropriate to mention them here, since they offer important advantages to the alimony claimant.

The first of these provisions (the new Section $85^{0-c}$ of the Code of Civil Procedure) concerns the case where the debtor arranges with his employer that his salary shall be paid to a third person, for example, to a second wife. In this case it is simply provided that the creditor of the employee shall have the same rights of garnishment as if the salary were paid directly to the employee.

The second provision concerns the case where the debtor, in order to deprive himself of leviable income, works for another gratuitously, for example, for a second wife to whom he has conveyed his business. For this case Section $850-\mathrm{d}$ provides, "In case a debtor standing in a continuing relation to a third person shall render services to that person which are customarily remunerated according to their kind and extent, an appropriate remuneration shall, as between the creditor and the recipient of such

\footnotetext{
${ }^{21}$ Section 850-b, as amended, renders immune from execution, within certain defined limits, the salaries of ordinary persons falling outside the classes (officials, ministers, public teachers, etc.) dealt with in $\$ 850-a$. Like the immunity provided in $\$ 850-a$, and subject to the same conditions and qualifications, this immunity is suspended in favor of one asserting a statutory claim to support. $\$ 850-\mathrm{b}$ also provides for extending the exemption from execution to a larger sum or to a larger proportion of the employec's salary or wage where this is necessary to allow him to meet obligations to provide support.
} 
services, be deemed to be due the debtor. In determining whether the conditions just mentioned are fulfilled, as well as in estimating the value of the services, all of the circumstances of the case are to be taken into consideration, including especially the nature of the services rendered, kinship or other relation existing between the person rendering the services and the recipient of them, and the economic condition of the latter."

The significance of these two provisions lies, first, in the fact that when the conditions prescribed in them are satisfied they make possible an immediate garnishment in favor of the "defrauded" creditor without compelling him first to engage in a time-consuming and expensive suit against the third person. A further significance lies in the fact that the presence of the prescribed conditions is itself determined in an informal procedure before the judge hearing the application for garnishment process.

\section{Alimony and Income Taxation}

The treatment of alimony payments for purposes of taxation, both from the standpoint of the obligor and that of the obligee, is worthy of brief mention.

In so far as the support provided exceeds the statutory liability of the obligor, as declared by the court, the payments are subject to the gift tax, the burden of which falls on the donor, in this case, the alimony obligor. According to Section 12 of the Income Tax Law of February 6, $193^{8}$ the obligor cannot deduct payments of alimony from his taxable income. Under some circumstances, however, he can secure a certain reduction in his taxes when he establishes that the payments represent for him an unusual burden. ( $\$ 33)$ According to Section 22, alimony payments do not form a part of the taxable income of the recipient. The situation is altered, however, when the payments of alimony are continued without statutory ground, as for example in case of the remarriage of the obligee. In this case, the party paying them may deduct them from his taxable income, while the recipient must pay an income tax on them. ${ }^{22}$

\section{Statistics}

Unfortunately it has not been possible to obtain relevant statistics concerning the number, character, and disposition of the claims to alimony annually asserted in Germany. The existing official statistics are not so arranged as to yield the insights into social conditions which could be obtained from complete statistical information in this field.

The publications of the Statistical Office of the Reich do, however, give the number of divorces granted annually in Germany, subdivided according to the fault of the parties as found by the court. These figures are not without relevance to the subject of alimony, since according to the Civil Code alimony was granted only to an innocent spouse, and, where both spouses were at fault, no claim to alimony was granted at all.

\footnotetext{
${ }^{23}$ Reichsfinanzhof in ReIchssteUterbLATT, I933, p. I008, and May 9, 1934, III, A, 58/34; JURIStische WOCHENSCHRIFT, 1934, p. 139.
} 
The figures for the last three years available are as follows:

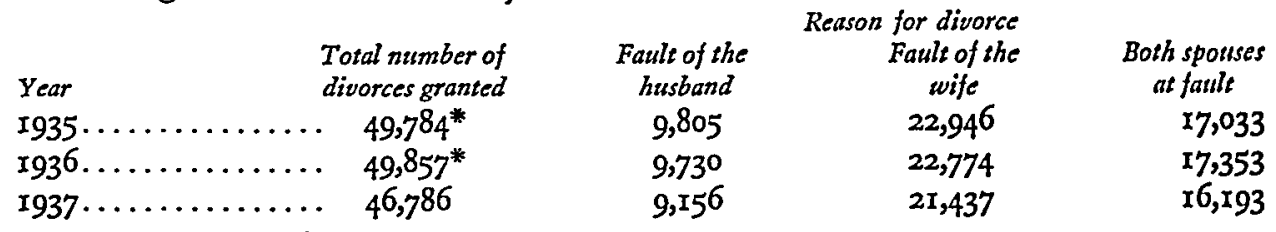

- The Saar is not included.

The figures given must, however, be used with great caution. Precisely because the Code made the claim to alimony dependent upon the court's finding concerning fault in the divorce proceeding, that proceeding was often consciously given a certain orientation, and fault was either artificially attributed or silently passed over in order to bring about the desired consequences for the financial claims between the spouses. Furthermore, the husband, in view of the social disadvantages to the wife resulting from an attribution of fault to her, may, in violation of the actual truth of the case, have assumed a part or all of the fault in those cases where the wife had waived any claim to alimony.

Bibliography of Literature Concerning the New Statutes

Begründung des Gesetzes, Deutsche Justiz, 1938, p. rro2. (Also published in Neuss EHEREcht, infra.)

Moessmer, Neugestaltung des Deutschen Ehescheidungsrechts, vorgelegt von dem Vorsitzenden des Familienrechtsausschusses der Akademie für Deutsches Recht, ScHrirten Der Akademie fuer Deutsches Recht (Berlin).

Neues Eherecht (Deutscher Rechtsverlag, Berlin, I938). Published in two parts containing, in Part I, the text of the Law of July $6, x 93^{8}$, and the text of the statutes referred to in that law, and in Part II, the complementary regulations of July 27 , x938, a selection from the statute concerning personal status, the official explanation of the Law of July 6, 1938, and a reprint of the article, Auf den Richter kommt es an, Das Schwarze KORPS, July $28, \mathrm{x} 938$.

Auert, Das neue grossdeutsche Eherecht (Walter de Gruyter \& Co., Berlin, 1938). (Second edition of "Die Eheaufösung im neuen deutschen Recht"). Contains not only the text of the new law, but also detailed explanations of its individual provisions, and an appendix on the divorce of foreigners under German law.

Volkmar, Das neue Eheschliessungs- und Ehescheidungsrecht, Deutsche Justiz, 1938, pp. III8 und Ir 45 .

Rexroth, Das Ehegesetz vom 6 Juli 1938, ReichsverwaltungsblatT, 1938, p. 633 .

Gutjahr, Das neue deutsche Ehegesetz, Deutsches Recht, 1938, p. 311.

Roquette, Schuldfeststellung und Schuldabwägung, Deutsches REchr, 1939, p. r9.

Blunck, Unterhaltspflicht des schuldig geschiedenen Ehemanns, JURIstische WocheNSCHRIFT, I938, p. 3I4.

Weise, id., JURISTISCHE WOChENSChrift, r939, p. 21.

Rilk, id., JuRISTISCHE WOCHENSCHRIFT, I939, p. 7r.

Wittmann, Rückwirkende Verwirkung des Unterhaltsanspruchs der Ehefrau, Jorustische WOCHENSCHRIFT, I938, p. 3083.

Rexroth, id., JURISTISChE WOCHENSCHRIFT, 1938, p. 3085.

Haselhoff, Zum neuen Eherecht, Deutsche Justiz, 1939, p. 216.

Friedrich, Steuerrechtliche Folgen der Unterhaltsregelung bei Ehescheidung, Juristische. WOCHENSCHRIFT, I938, p. 2446.

Ruchling, Recht der LohNpfaendung (Berlin, i938). 